\title{
Agricultural expansion in Uruguayan grasslands and priority areas for vertebrate and woody plant conservation
}

\author{
Alejandro Brazeiro $^{1}$, Marcel Achkar $^{1}$, Carolina Toranza $^{1,2}$ and Lucía Bartesaghi $^{1}$
}

\begin{abstract}
Habitat loss due to land-use change is the greatest threat to biodiversity on a global scale, and agriculture has been the principal driver of change. In Uruguay, the conversion of native grasslands to croplands (e.g., soybean) and exotic forest plantations (Eucalyptus and Pinus) has accelerated during the last two decades. We studied the vulnerability of vertebrate and woody plant diversity to the loss of grassland areas, driven by agricultural and forestry expansion, to identify priority areas for conservation. We assessed the spatial variability of biodiversity vulnerability in function of species richness and number of focal species (i.e., prioritized species) of woody plants and terrestrial vertebrates that use grassland ecosystem as habitat. The top 17\% of vulnerable sites (51 of 302 cells) were selected as priority conservation areas for Uruguay, following Aichi Target number 11. Approximately $36 \%$ of the original continental territory of Uruguay, mainly grasslands, was converted to cropland $(28 \%)$ and exotic forest plantations $(8 \%)$ in 2015 . Approximately $27 \%$ of the priority cells for conservation of vertebrates and woody plant diversity have been transformed, especially in three ecoregions in which habitat loss was between $35-45 \%$. We simulated a land-use scenario for 2030, based on national production goals of soybean and exotic forest plantations, projecting that: (1) the overall loss of original habitat (mainly grasslands) would reach $48 \%$ of the country's land area, and (2) $45 \%$ of the priority cells would be converted to agricultural lands, especially in four ecoregions, with habitat losses greater than $50 \%$. Our results suggest an urgent need to develop strategies to reduce the rate of natural grassland loss in Uruguay, as well as to conserve biodiversity and ecosystem services associated with these systems. Conservation efforts should focus on prioritized cells, especially those with no protection status and a high likelihood of agricultural conversion in 2030, through expanding public and private protected areas and promoting wildlife-friendly agricultural alternatives, such as beef production in natural grasslands.
\end{abstract}

Key Words: agricultural expansion; biodiversity vulnerability; conservation priority; exotic forest plantation; grasslands; soybean crop

\section{INTRODUCTION}

Humans have been transforming and replacing ecosystems across most of the terrestrial biosphere throughout history (Ellis et al. 2010). About half of the terrestrial ice-free area has been modified by human activities, through replacing and modifying natural habitats by agricultural and urban systems (Chapin et al. 1997, Kareiva et al. 2007, Ellis et al. 2010). At the global scale, agriculture has been the principal driver of land-use change. The expected increase in global consumption suggests a strong increase of global food demand until 2050 (Green et al. 2005, Bodirsky et al. 2015), thus increasing the pressure to further expand productive areas (e.g., Popp et al. 2017). Land-use and land-cover change (we use "land-use change" for simplicity) are key drivers of the present loss of biodiversity and associated ecosystem services in terrestrial ecosystems (Vitousek 1994, MEA 2005, Haines-Young 2009), which is expected to continue in the future under certain socioeconomic scenarios (Sala et al. 2000, Newbold 2018).

The historical process of land transformation has been highly heterogeneous across the surface of the earth, with some biomes and regions almost entirely transformed and others almost uninfluenced by direct human activity (Ellis et al. 2010). Nowadays, the loss of natural forests (e.g., tropical rainforest) is a focus of attention for scientists and the public but the highest levels of anthropogenic transformation have occurred in open biomes. The greatest historical land-use changes have occurred in grasslands, savannas, and shrublands, with all of these experiencing more than $80 \%$ of land-use conversion from 1700 to 2000 (Ellis et al. 2010). Most of this land-use change was the result of converting both wildlands and seminatural lands to rangelands and croplands. In the case of temperate grasslands, about $41 \%$ worldwide have been converted to agricultural use, another $6 \%$ to urbanization, and an additional $7.5 \%$ to commercial forestry and other disturbances (White et al. 2000). Today temperate grasslands are considered the most altered terrestrial ecosystem on the planet and are recognized as the most endangered ecosystem on most continents because they have the lowest level of protection (about 4\%) among the world's 14 biomes (Henwood 2010). The consequences of land-use changes on biodiversity have been relatively less studied in temperate grasslands, particularly in South America (Henwood 1998, 2010, IUCN 2009).

The Río de la Plata Grasslands is one of the largest complexes of grasslands in South America, covering more than $750,000 \mathrm{~km}^{2}$ in the vast plains of central-east Argentina, southern Brazil, and Uruguay (Soriano et al. 1992, Paruelo et al. 2007). It comprises two ecoregions, the Pampas (Argentina) and the Uruguayan Savannas or Campos (Uruguay, Brazil, and Argentina; Soriano et al. 1992, Dinerstein et al. 1995). During the conservation assessment of the terrestrial ecoregions of Latin America and the Caribbean (Dinerstein et al. 1995), excessive grazing by livestock and the conversion of natural habitats to agriculture were identified as the primary threats to biodiversity. During the last two decades, the rate of grassland conversion to croplands and exotic forest plantations has been alarming in this region, mainly driven by the high price of commodities (e.g., soybean) in the international market (Jobbágy et al. 2006, Paruelo et al. 2006, Baldi and Paruelo 2008, Modernel et al. 2016).

${ }^{1}$ Facultad de Ciencias, Universidad de la República, Uruguay, ${ }^{2}$ Departamento de Producción Forestal y Tecnología de la Madera, Facultad de Agronomía, Universidad de la República, Uruguay 
The Río de la Plata Grasslands includes a diversity of ecosystems. In addition to several grassland types, there are other marginal but well-distributed ecosystems, such as native forests, woodlands, savannas, shrublands, wetlands, and several aquatic systems (Soriano et al 1992). This variety of habitats sustains a substantial levels of species diversity, with thousands (2000-4000) of vascular plants including more than 500 graminoid species, approximately 100 species of mammals, and over 500 bird species (Bilenca and Miñaro 2004, Overbeck et al. 2007). Recent evidence has suggested that landscape modification in the Río de la Plata Grasslands due to land-use change could have significant impacts on plant and animal diversity as well as on the provision of ecosystem services (Overbek et al. 2007, Medan et al. 2011, Aspiroz et al. 2012, da Silva et al. 2015, Modernel et al. 2016, Paruelo et al. 2016). The evidence reported in these studies, mainly on birds and mammals of the Argentinean Pampas, shows that agricultural expansion has reduced the geographic ranges and/or abundance, sometimes leading to regional extinction, of many mammal and bird species, including grassland specialists and large herbivores and carnivores. Other species were unaffected (birds) or also benefited (bird, rodent).

In Uruguay, land-use change has been relatively moderate within the context of the Río de la Plata Grasslands, but the conversion of wildlands and rangelands to croplands (mainly soybean) and exotic forest plantations (mainly Eucalyptus) has accelerated over the last two decades (Dinerstein et al. 1995, Baldi and Paruelo 2008, Henwood 2010). The agricultural sector is a crucial component of the Uruguayan economy, highly specialized in commodities and services based on natural resources, which comprise $70 \%$ of total exports (Sandonato and Willebald 2018). The economic strategy of Uruguay is heavily based on the growth of this productive sector and, therefore, specific national goals of growth have been delineated for the future (2030) by the Office of Planning and Budget (OPP) of the Presidency of the Republic of Uruguay (OPP 2009). The fulfilment of these goals implies a significant expansion in crop cover and exotic forest plantations in the next decade. This represents an important challenge for the sustainable development of Uruguay. Conservation planning, focusing on species vulnerable to agricultural expansion, is key to developing efficient conservation measures that protect biodiversity in such intensively managed agricultural landscapes. Some spatial prioritization studies for biodiversity conservation have been carried out in the region (e.g., Bilenca and Miñaro 2004, Brazeiro et al. 2008, 2015a, Soutullo and Bartesaghi 2009, Nori et al. 2016), but to our knowledge, research has not focused on vulnerability to agricultural expansion, even though it is recognized as the main threat to biodiversity in our region.

We analyzed the vulnerability of the diversity of vertebrates and woody plants of Uruguay to the loss of grassland areas, driven by agricultural and forestry expansion, to identify priority areas for conservation. Three main questions are addressed: (1) where are the most vulnerable areas for vertebrates and woody plants conservation located? (2) to what extent have the areas of highest vulnerability been converted to croplands and afforestation, or are expected to be impacted in the near future by agricultural expansion? and (3) where to prioritize efforts to conserve vertebrates and woody plants in the face of future agricultural expansion?

\section{METHODS}

\section{Study area}

Uruguay, located $\left(30^{\circ} 05^{\prime} 08^{\prime \prime}-34^{\circ} 58^{\prime} 27^{\prime \prime} \mathrm{S}, 53^{\circ} 10^{\prime} 58^{\prime \prime}-58^{\circ} 26^{\prime} 01^{\prime \prime} \mathrm{W}\right)$ in southeast South America, has a continental area of 176,215 $\mathrm{km}^{2}$. The climate is temperate (Cfa, sensu Köppen-Geiger), with mean annual temperature ranging between 16 and $20^{\circ} \mathrm{C}$ and mean annual rainfall between 1100 and $1400 \mathrm{~mm} / \mathrm{y}^{-1}$. The temperature is strongly seasonal, and rainfall is evenly distributed during the year, but strongly variable between years (see INUMET: https:// www.inumet.gub.uy/clima/climatologia-estacional).

Grasslands, including prairies and open woodlands, occupied more than $80 \%$ of the territory in the Pre-Hispanic period, representing the matrix ecosystem in the landscape, in combination with dispersed patches of native forests, woodlands, and wetlands (CLAES 2008). The main land uses are livestock, cropping, and exotic forest plantations covering about $90 \%$ of the territory (MGAP 2016). Cattle breeding for meat and milk production on natural/seminatural grasslands is the dominant productive activity, and soybean, wheat, rice, barley, sunflower, and maize are the main annual crops (MGAP 2016). In the forestry sector, Eucalyptus (E. globolus and E. grandis) and Pinus (P. ellottii, $P$. taeda, $P$. pinaster) species are the most extensively planted in afforestation systems (Petraglia and Dell'Acqua 2006).

Seven natural ecoregions can be distinguished in Uruguay according to geomorphology, soils, physiography, and biota (vertebrates and woody plants; Brazeiro et al. 2015a), which are used as inputs for conservation planning in the National Strategy of Biological Diversity (MVOTMA 2016) and Protected Areas Plan (SNAP 2015).

Assessing biodiversity vulnerability to agricultural transformation According to a risk assessment framework (Villa and McLeod 2002), we operationally defined vulnerability as the susceptibility of ecosystems to suffer degradation in their conservation value, due to loss of natural habitat by the implantation of crops or exotic productive forests. Thus, the quantity of valuable and susceptible elements of a given area defines its vulnerability level.

In Uruguay, agricultural expansion affects almost exclusively grasslands and other open ecosystems (shrublands, wetlands), because natural forests, including palm and park savannas, are legally protected $\left(\mathrm{N}^{\mathrm{o}} 15.939 / 1988\right)$. Illegal logging of natural forests is very marginal, and there is evidence that forest area has increased during the last 50 years (MGAP 2018, National Forest Strategy). Therefore, grassland and open habitat species (from here, we refer to them as grassland species, for simplicity), are clearly more susceptible than forest species to agricultural transformation. Among grasslands species, those endangered, geographically restricted, endemic, or functionally relevant should be of special conservation concern. Species fulfilling such prioritization criteria were named as focal grassland species in this study. So, we used two kinds of biodiversity indicators commonly included in prioritization studies (e.g., Wilson et al. 2009, Reece and Noss 2014, IUCN 2016) to develop a site vulnerability index (VI): the richness of vulnerable species and focal species. We calculated VI as a function of the richness of grassland species (GS) and the richness of focal grassland-species (FGS). Vulnerability index, varying between 0 and 100, was calculated as a weighted sum of the two indicators (weight; VI: 
40, FGS: 60), previously standardized to vary between 0 and 1, using the following equation: $\mathrm{VI}=(\mathrm{GS} \times 40)+(\mathrm{FGS} \times 60)$.

We used the spatial database of records and potential occurrences of 853 species of woody plants and terrestrial vertebrates (i.e., amphibians, reptiles, birds, and mammals) reported by Brazeiro et al. (2015b) to calculate GS and FGS. The records and potential occurrences (obtained from models and expert opinions) of species are given over a grid of 302 cells of $33 \times 20 \mathrm{~km}$, covering the entire Uruguayan territory. Previous version of this database have been used in other publications (e.g., Canavero et al. 2010, Carreira et al. 2012, Haretche et al. 2012, Pérez-Quesada and Brazeiro 2013, Brazeiro et al. 2015a) and to design the management plan of the National System of Protected Areas of Uruguay (SNAP 2015). From this species assemblage, we selected all species that use grasslands and/or shrublands as exclusive (i.e., habitat specialists) or secondary habitats (i.e., habitat generalists), according to recent local bibliography on woody plants (Brussa and Grela 2007, Haretche et al. 2012), amphibians and reptiles (Achaval and Olmos 2007, Maneyro and Carreira 2012, Carreira and Maneyro 2013), birds (Aspiroz 2001, Aspiroz and Blake 2009), and mammals (González and Martínez-Lanfranco 2010), and recent actualization by local experts (see Brazeiro et al. 2015b).

To obtain FGS, we defined as focal grassland species those grasslands woody plants and terrestrial vertebrates included in the national list of priority species for conservation (Soutullo et al. 2013). This priority species list was defined using classic conservation criteria (i.e., endangered, geographically restricted, endemic, functionally relevant, and valuable species) and today is largely utilized in environmental planning and management in Uruguay.

\section{Selecting priority vulnerable areas to agricultural transformation}

The selection of the priority-vulnerable areas was performed using a threshold of the $17 \%$ highest vulnerability cell, following the Aichi Target number 11, which aims to ensure that by 2020 at least $17 \%$ of ecosystems are protected, especially those of greater importance for biodiversity and ecosystem services. Thus, we decided to highlight $17 \%$ of the cells of the country, i.e., 51 cells (of 302), as the priority-vulnerable areas. The 51 cells were proportionally distributed among the 7 ecoregions of Uruguay according to their area, to incorporate the criteria of representativeness, and complementarity in the prioritization approach (following Margules and Pressey 2000). The cells with the highest vulnerability of each ecoregion were selected, until the allocated number of cells per ecoregion was reached.

\section{Land-use dynamics and present mapping}

The overall land-use change pattern of Uruguay between 1990 and 2015 was rebuilt integrating different data sources: (1) official agricultural census of 1990, 2000, and 2011 from the Direction of Agricultural Statistics (DIEA: http://www2.mgap.gub.uy/portal/ page.aspx?2,diea, diea-principal, O,es,0), national forest inventories of 1990, 2000, 2005, 2010, and 2015 from the Forest Department (DGF: http://www.mgap.gub.uy/sites/default/files/multimedia/ uruguayfra2015.pdf), and land-cover maps of 2000, 2008, 2011, and 2015 from the Ministry of Environment (MVOTMA: $\underline{\text { http:// }}$ sit.mvotma.gub.uy/websdatos/cobertura.html).

We used the official land-cover shapefile of 2015, available at the website of the Ministry of Environment of Uruguay (MVOTMA), to describe the current pattern of land-use change. This shapefile contains the land-cover classification performed by analyzing a set of LANDSAT 5TM scenes, with a spatial resolution of $30 \mathrm{~m}$. Land cover was classified using the FAO system (LCCS), with a total of 48 classes integrated in 8 major classes: (1) cultivated and managed terrestrial areas; (2) artificial surfaces and associated areas; (3) artificial waterbodies, snow, and ice; (4) cultivated aquatic or regularly flooded areas; (5) natural and seminatural vegetation; (6) natural and seminatural aquatic or regularly flooded vegetation; (7) bare areas; and (8) natural waterbodies, snow, and ice. The resulting classification was checked in the field and good levels of accuracy were reported, for example, $94.3 \%$ in cultivated and managed terrestrial areas and $94.6 \%$ in natural and seminatural vegetation, during the land-cover classification of 2008 (MVOTMA 2012).

The first four major classes were integrated into a superclass, "highly transformed areas," to estimate natural habitat loss since the Pre-Hispanic period. The main class, cultivated and managed terrestrial areas, was disaggregated into two subclasses, i.e., croplands and exotic forest plantations, the most important landuse drivers in Uruguay. To integrate land-use and biodiversity vulnerability data, we crossed the shapefiles of croplands, exotic forest plantations, and highly transformed areas with the shapefile containing the grid ( 302 cells of $33 \times 20 \mathrm{~km}$ ). Finally, we summed and mapped the areas of croplands, exotic forest plantations, and highly transformed areas by cell. Geoprocessing was performed in QGIS 2.18.

\section{Projecting future land use: scenario 2030}

Regional land-use models often adopt a two-phase approach, beginning with an assessment of aggregate quantities of land use for the entire region, and following with a downscaling procedure to create fine resolution land-use patterns (de Chazal and Rounsevell 2009). The general two-phase approach used in our study is illustrated in the flowchart presented in Figure 1. In our case, the total quantity of land use projected for 2030 (phase one) was derived from the national goals of economic growth for 2030 , proposed by the Office of Planning and Budget (OPP) of the Presidency of the Republic of Uruguay, as a target scenario (OPP 2009). The Office of Planning and Budget proposed national goals of economic growth for $2030\left(\mathrm{GDP}_{2030}\right.$ : US\$68,707 x $10^{6}$, Growth Rate $_{2008-2030}: 5.0 \%$, Exports $_{2030}$ : US\$22,028 x 10 ${ }^{6}$, which are based on the goals of production for each economic sector (OPP 2009).

In Uruguay, the main economic sector driving land-use change is agriculture (cropping and exotic forest plantation), which is responsible for $93 \%$ of the transformed land cover of Uruguay; the other $7 \%$ are urban areas, infrastructures, and artificial water bodies (MVOTMA 2012). To achieve the national production goals for 2030 proposed by OPP (2009), it would be necessary to increase by approximately $1,000,000$ ha the area of both croplands and exotic forest plantation. Among crops, soybean has been the main driver of agricultural expansion over the last two decades, whereas the planted area of other crops has remained relatively constant (MGAP 2016). Thus, we focused on soybean expansion to develop the 2030 scenario and assumed that the area of other crops will remain constant until 2030. These production targets are in-tune with the growing trend of the international prices of soybean and wood pulp observed from 2000 to date, despite the high variability among years. 
Fig. 1. Flowchart describing the procedure used to build the land-use scenario for 2030.

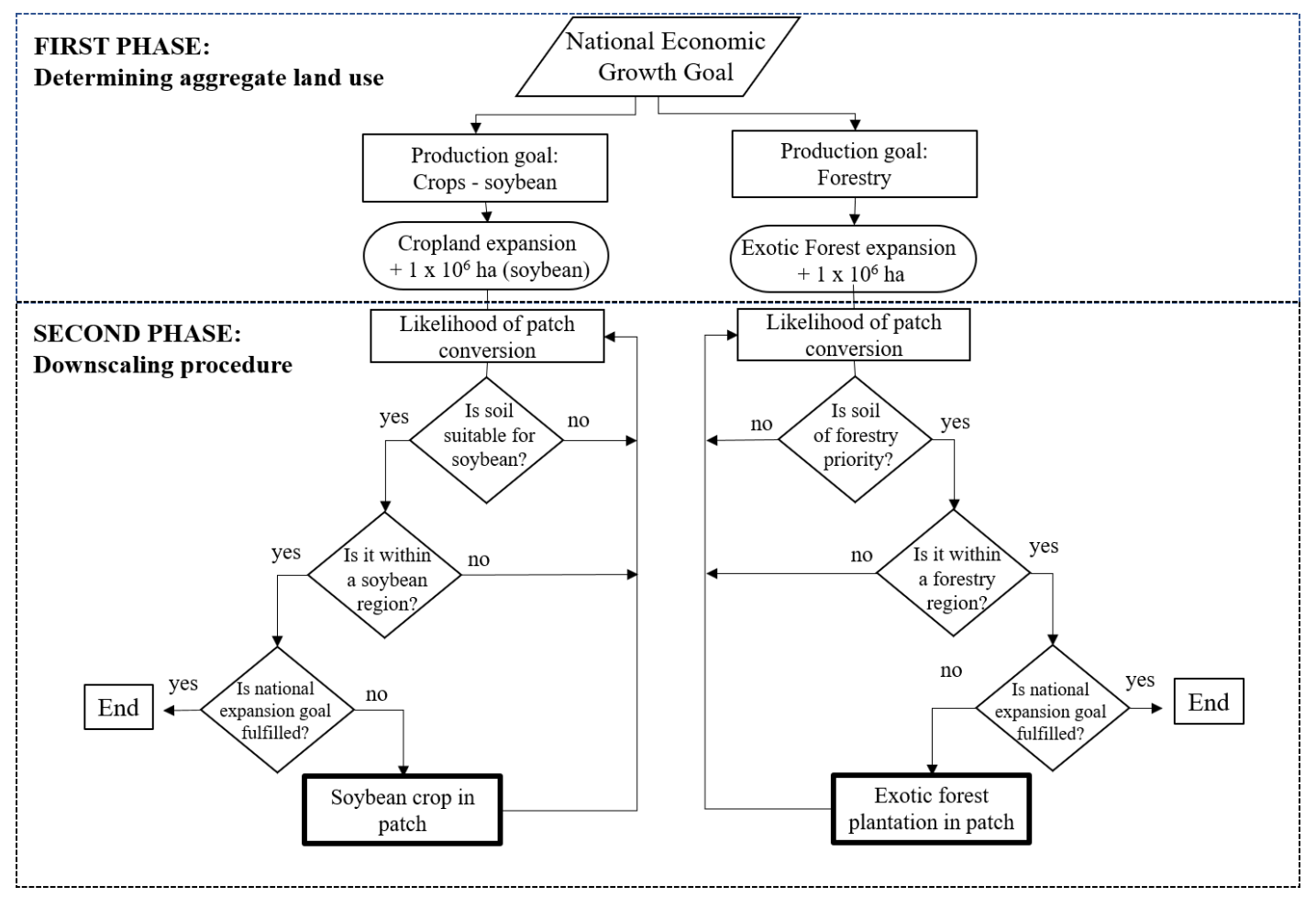

The downscaling procedure (phase two) to create a fine-resolution spatial pattern of exotic forest plantations for 2030 was based on the following assumptions about forestry expansion: (1) preference for the legally defined priority areas (Decrees 452/988 and 220/06, Forestry Direction/MGAP), according to the observed trend during the last 20 years; (2) within priority areas, the preference is to consolidate the four established forestry regions (northeast, west, centre, and southeast) because of logistic advantages; (3) development of new forestry region of 100,000 ha in suitable soils (5.02b category, sensu CONEAT 1979) surrounding $(<200 \mathrm{~km})$ the new $(2014)$ cellulose pulp plant of Montes del Plata (MDP) in the locality of Conchillas (Colonia) because of the higher profitability associated with lower transport costs. Montes del Plata has already made efforts in such directions. Using these assumptions, we assessed the conversion likelihood of all natural and seminatural vegetation patches (polygons) detected in the land-cover map of 2015. The assessment included two sequential questions (Fig. 1): (1) is the patch located in forestry priority soil? and (2) is it included within a consolidated forestry region (i.e., $<100 \mathrm{~km}$ from the regional centre. Are closer patches planted first?)? If both answers were "yes," we assumed the conversion likelihood of this patch is one, and thus the patch was converted to forest plantation in the 2030 scenario. This logic continued with the assessment of other patches, until the cumulative converted area reached the national expansion goal (phase one), and the process was stopped.

In the case of soybean expansion over natural/seminatural vegetation patches, a fine-scale spatial projection was based on the following assumptions: (1) preference for soils of high aptitude for agriculture because soil suitability is an important determinant of crop profitability. We defined the likelihood of soybean expansion (p) as function of soil aptitude for soybean crops, using four categories: highly suitable $(\mathrm{p}=1)$, suitable $(\mathrm{p}=$ $0.8)$, marginally suitable $(p=0.5)$, and unsuitable $(p=0)$. Spatial information of soil suitability was obtained from the Soils Map of Uruguay $(1: 1,000,000)$, using the index of soils suitability for summer crops of Cayssials and Álvarez (1983). (2) Among equally suitable patches, the likelihood of conversion is proportional to the proximity to the centre of the agricultural regions already consolidated (south, southwest, centre, west, northwest, and east) because of logistic advantages. These assumptions were used to assess the conversion (to soybean crop) likelihood of all natural and seminatural vegetation patches detected in the land-cover map of 2015. The assessment also included two main sequential questions (Fig. 1), following the same logic described for exotic forest plantation.

In some cases, the likelihood of conversion to forest plantation and soybean crop were comparable. In such cases, we assumed that soybean was preferred over forest plantation because of its higher economic profitability.

Finally, to make the land-use scenario for 2030 spatially comparable with our biodiversity data, the patch-level data were summed and mapped over the grid of 302 cells of $33 \times 20 \mathrm{~km}$. Geoprocessing was performed in QGIS 2.18.

\section{RESULTS}

\section{Biodiversity vulnerability and ecoregional priorities for} conservation

Half of the species of woody plants and terrestrial vertebrates of Uruguay use grassland ecosystems as habitat, and about $11 \%$ of them are focal species because of their precarious conservation 
status or high ecological or social value (Table 1). The richness of grassland species showed broad geographic variability, with the west and east fringes and the southeast region being the most diverse (Fig. 2a). Focal species richness showed a somewhat similar pattern to overall grassland species (Fig. 2b), being positively and significantly correlated in space (Spearman-rank correlations: $\left.\mathrm{r}_{\mathrm{S}}=0.91, \mathrm{P}<0.0001\right)$. Therefore, the biodiversity vulnerability index to land-use change, derived from the previous indicators, also resembled the spatial pattern of grassland species richness. High-vulnerable cells are mainly concentrated in five ecoregions: (1) northern zone of the Western Sediment Basin; (2) northern and eastern zones of the Gondwanic Sediment Basin; (3) northeast of Eastern Sierras; (4) southern zone (Atlantic fringe) of the Merin Lagoon Graven; and (5) south (Atlantic fringe) of the Santa Lucía Graben (Fig. 2c).

We identified 51 cells $(\sim 17 \%$ of 302$)$ as the priority vulnerable areas of the country that were proportionally distributed among the 7 ecoregions (Fig. 2c). All prioritized cells were located in the regions of the high vulnerability described above, or nearby. Currently, seven priority cells $(13.7 \%)$ overlap with protected areas of the national system (SNAP; Fig. 2c).

Table 1. Species richness of terrestrial vertebrates and woody plants of Uruguay. For each group, the total number of species in the country (Total), the number of species using grassland as habitat (Grassland species) and the number of Grasslands species prioritized at the national level in Uruguay (Focal species) are given.

\begin{tabular}{lccc}
\hline \hline & \multicolumn{3}{c}{ Number of species } \\
\cline { 2 - 4 } & Total & Grassland & Focal \\
\hline Amphibians & 48 & 4 & 1 \\
Reptiles & 65 & 36 & 18 \\
Birds & 351 & 222 & 28 \\
Mammals & 74 & 55 & 14 \\
Woody plants & 315 & 114 & 34 \\
Total (\%) & $853(100 \%)$ & $431(50.5 \%)$ & $95(11.1 \%)$ \\
\hline
\end{tabular}

\section{Land-use change: present patterns and future projections}

Land-use dynamics in Uruguay resembled the regional pattern, showing a slow and gradual growth of agricultural lands during the 1990s and an accelerated expansion from 2000 (Fig. 3). Soybean has been the main driver of the acceleration phase, growing from less than 40,000 ha before 2000, to more than $1,200,000$ ha in 2015 . The other important driver of change has been the forestry sector, which has been encouraged by tax reductions during the late 1980s and 1990s, in certain zones and types of soils (forestry-priority zones, law $N^{\circ} 15.939$ of 1987). This policy triggered a pronounced development of exotic forest plantations, mainly with eucalyptus and pines, which rose from less than 200,000 ha before the 1990 s to more than $1,000,000$ ha in 2015 (Fig. 3).

According to the land-cover map of $2015,36.2 \%$ of the original continental territory of Uruguay $\left(176,500 \mathrm{~km}^{2}\right)$ has been transformed by croplands (including artificial prairies, 27.5\%), exotic forest plantations $(7.9 \%)$, and urban and other artificial areas $(0.8 \%)$. Croplands are mainly distributed in the southwest and west regions, and in part in the east (Fig. 4). The forestry
Fig. 2. Identifying the cells of high diversity of vulnerable species to agricultural expansion in Uruguay. (a) Species richness of woody plants and terrestrial vertebrates of Uruguayan grasslands. (b) Species richness of grassland focal species (i.e., nationally prioritized species). (c) Vulnerability map. The highest (i.e., top 17\%) vulnerable cells for each ecoregion and the protected areas of the national system were highlighted. The ecoregions of Uruguay are indicated according to the following codes: Western Sediment Basin (WSB), Basaltic Slope (BS), Crystalline Shield (CS), Gondwanic Sediment Basin (GSB), Merin Lagoon Graben (MLG), Santa Lucía Graben (SLG), and Eastern Sierras (ES).

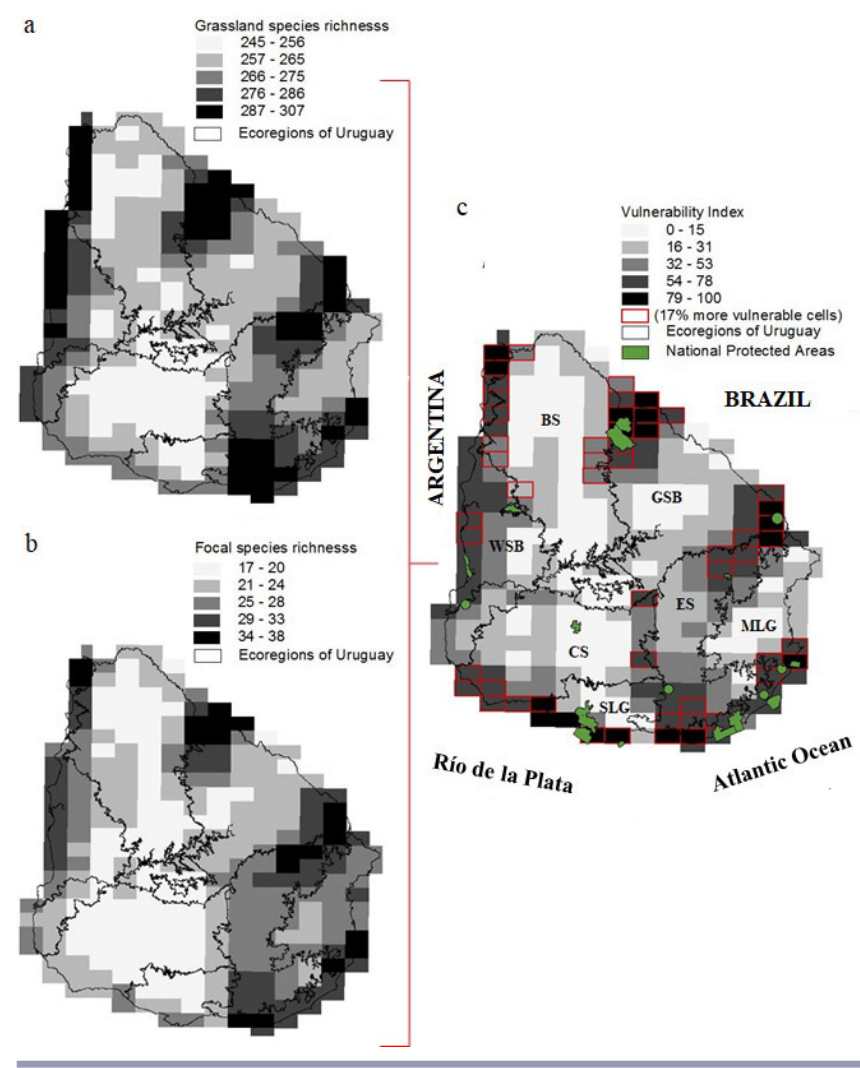

Fig. 3. Dynamics of land transformation by soybean crop, other crops, exotic forest plantations, and urban areas in Uruguay between 1992 and 2015 (solid lines), rebuilt using different sources of official data (see text for details). Dashed lines indicate the projected land-use scenarios for 2030.

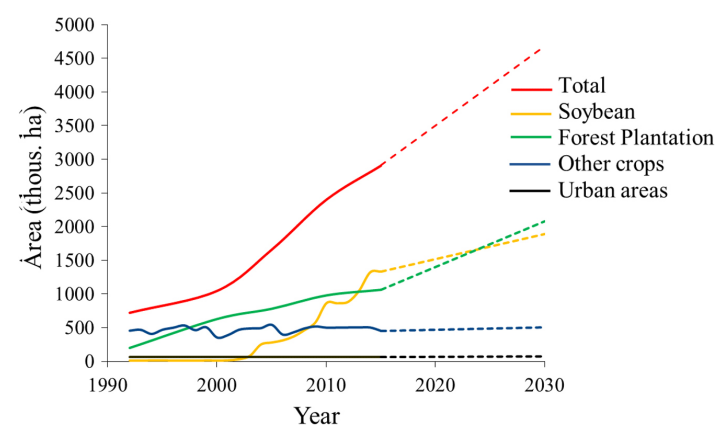


Fig. 4. Original habitat loss by land-use changes in 2015, and projected loss in the 2030 scenario because of soybean and exotic forests expansions. The highest (i.e., top 17\%) vulnerable cells for conserving the vertebrate and woody plant diversity per each ecoregion are highlighted.

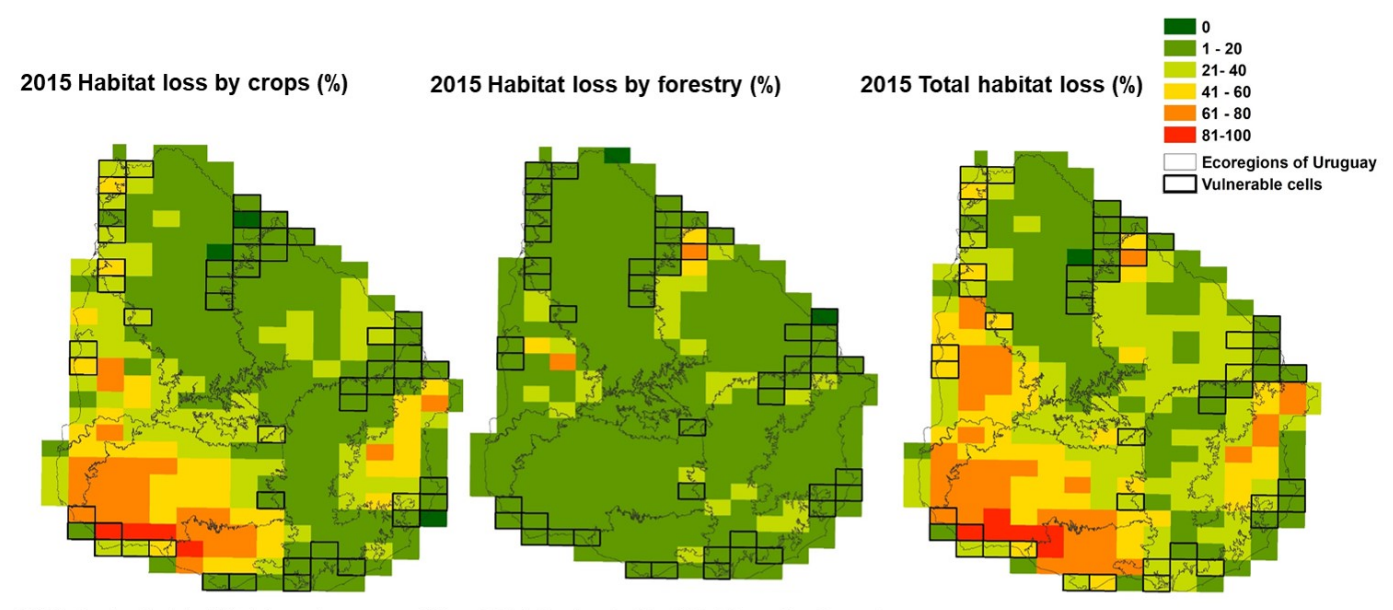

2030 Projected habitat loss by crops (\%)

2030 Projected habitat loss by forestry (\%) 2030 Total projected loss of habitat (\%)
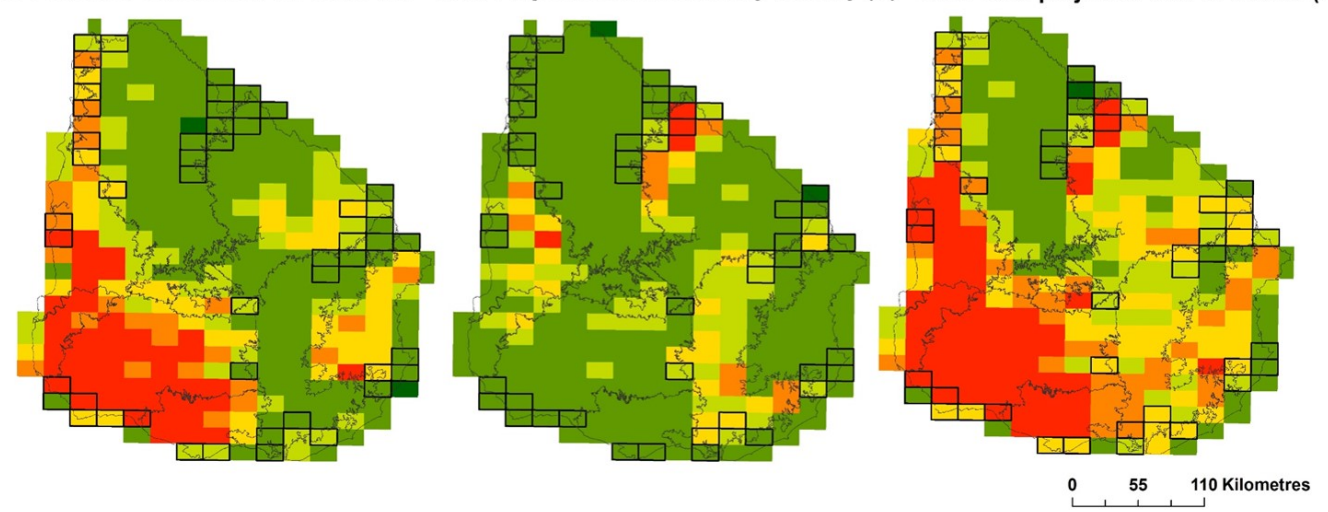

sector is mainly distributed in four regions, with the west and northeast regions containing the most extensively planted areas (Fig. 4). At present, the ecoregions most affected by land-use change have been the Santa Lucia Graben (SLG), Crystalline Shield (CS), and the Western Sediment Basin (WSB) with an overall loss of natural habitat, mainly grasslands, of about $50 \%$ or greater (Fig. 5a). The Merin Lagoon (MLB) and the Gondwanic Sediment Basin (GSB) ecoregions present intermediate levels of natural habitat conversion (20-30\%), whereas the Basaltic Slope (BS) and the Eastern Sierras (ES) ecoregions showed the lowest levels $(<20 \%$; Fig. 5a).

In the projected land-use scenario for 2030, croplands will cover about $32.7 \%$ of the territory and exotic forest plantations about $15.2 \%$. If urban and other artificial areas remain at present levels $(0.8 \%)$, the total loss of original habitat would reach $48.7 \%$ of the country's surface area. Land-use change would be intensified in the three ecoregions highly transformed in 2015 (SLG, CS, and WSB), with natural habitat conversion of about $80 \%$ (Fig. $5 \mathrm{a}$ ). The MLG, ES, and GSB ecoregions would lose about $40 \%$ of their original habitat, and the BS ecoregion would be unchanged (Fig. 5a).

\section{Land-use change in conservation-priority sites}

At present, about $27 \%$ of the total area of the priority cells (51) has been transformed by land-use change in 2015, but there was substantial variability among ecoregions (Figs. 4 and 5b). Whereas four ecoregions (BS, MLG, ES, and GSB) suffered low conversion $(<25 \%)$ within their priority cells, in three ecoregions (SLG, CS, and WSB), the loss of natural habitat was between 30 and $40 \%$ (Fig. 5b). Land conversion in SLG was mainly driven by the urbanization of the capital city (Montevideo) and by croplands (Fig. 4). The priority cells of the CS and WSB ecoregions were mainly transformed by croplands and exotic forest plantation, respectively (Fig. 4).

Under the projected scenario for 2030, the overall habitat loss within priority cells would ascend to $45 \%$. One ecoregion would remain almost unchanged with less than $25 \%$ of habitat loss (Basaltic Slope) and two ecoregions will lose between 35 and $42 \%$ (MLG and ES; Fig. 5b). Four ecoregions (GSB, SLG, CS, and WSB) would be highly impacted by habitat loss (50-70\%) in their priority cells (Fig. 5b). The expansion of exotic forest plantations would be the main driver of land transformation in the priority cells of the GSB ecoregion, whereas croplands will be the main driver in the other three ecoregions (Fig. 4). 
Fig. 5. (a) Observed natural habitat loss per ecoregion in 2015 and projected loss according to the 2030 scenario. (b) Observed natural habitat loss at the priority cells (i.e., highest vulnerable cells, top $17 \%$ ) for diversity conservation of vertebrates and woody plants in 2015, and projected loss according to the 2030 scenario.

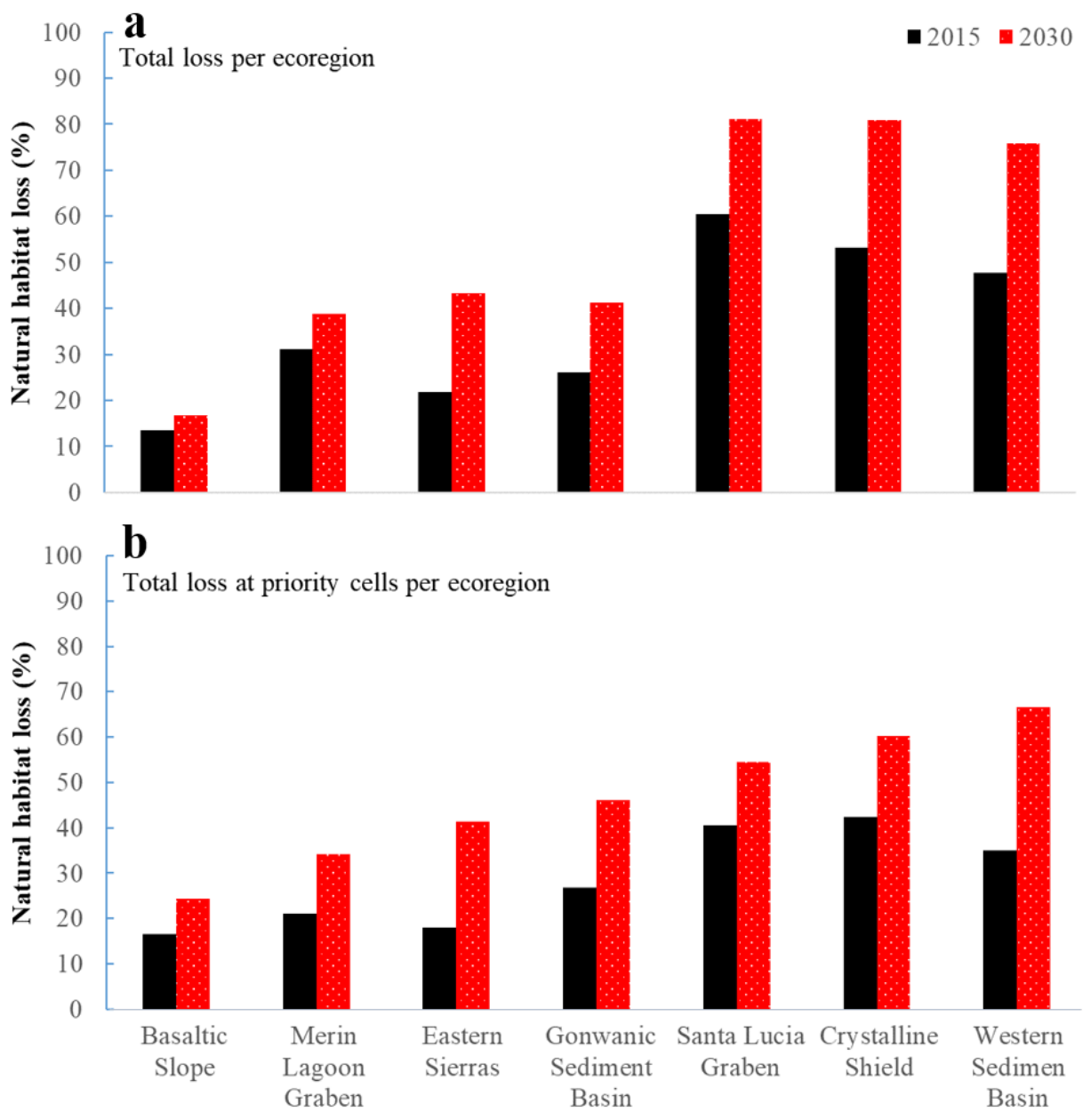

Ecoregion

\section{DISCUSSION}

\section{Agricultural expansion and loss of natural grasslands}

More than one-third of Uruguay's natural habitats, largely grasslands, have been converted into croplands, exotic forest plantations, and urbanization in 2015. The causes of land-use change in Uruguay during the last 30-40 years, as in the entire Río de la Plata Grassland region, have been largely discussed (see Paruelo et al. 2006, Baldi and Paruelo 2008, Modernel et al 2016). The high international prices of soybean and wood pulp, the accessibility to new technologies (i.e., no-tillage cropping and genetically modified organisms), and fiscal policies favorable to exotic forestry development (1980-1990s) have been the main drivers.

In the case of soybean, an annual crop, the dynamics of planted areas tracked very well, with a one-two year delay in the price of a metric ton in the Chicago market (http://www.indexmundi.com/ commodities/). For example, the peaks of the planted area observed in Uruguay during 2010 and 2015 (Fig. 3) were associated with growing prices during 2006-2008 and 2011-2014, respectively. Likewise, the observed drop in the planted area after the 2010 peak was associated with lower prices during the next years. After the 2015-peak, the historical maximum, a slow-down has occurred in the soybean expansion according to producers' declarations (MGAP 2019), differing from our model projection (Fig. 3). This slow-down in the planted area of soybean is also associated with lowering international prices. Despite the smallscale fluctuations, the international prices of soybean and wood pulp have been growing in the mid-long term, driving the agricultural expansion in Uruguay. Thus, we think that beyond the small-scale fluctuations, the global market of these commodities (i.e., soybean and wood pulp) will increase in the mid-long term, promoting the future expansion of the agricultural border in our region, ultimately supporting the 
production targets of the Uruguayan government for 2030 (OPP 2009).

The achievement of these national production targets of soybean and exotic forestry would imply the loss of almost half $(48 \%)$ of the natural habitat of Uruguay in 2030. In the case of the forestry sector, there are additional local pressures to expand the planted area. There are two cellulose pulp mills of high productivity capacity (1.1-1.3 X $10^{6}$ tons per year) operating in the country (one in the west and the other in the south) and recently a project was approved to open a third pulp mill in the centre of the country.

At present, three ecoregions (SLG, CS, and WSB) have lost about $50 \%$ of their original grasslands, which could have consequences in the delivery of critical ecosystem services, such as soil conservation, water provision, and habitat provision for diversity, as documented in previous studies in the region (e.g., Overbek et al. 2007, Medan et al. 2011, Aspiroz et al. 2012, da Silva et al. 2015, Modernel et al. 2016, Paruelo et al. 2016). Further land conversion within these ecoregions should be minimized or carefully studied to prevent environmental problems. For example, serious problems with water quality already exist in the Santa Lucía Graven ecoregion, affecting the water supply to the capital city of Uruguay (Montevideo) and the adjacent metropolitan region (Barreto et al. 2017).

\section{Vulnerability of vertebrates and woody plants diversity to grassland loss}

We found that almost half of the woody plants and terrestrial vertebrate species of Uruguay are vulnerable to agricultural expansion. These species use the grassland ecosystem, which has been largely converted to croplands and exotic forestry plantations in the country, as habitat. In spatial terms, vulnerability is higher where there are more species and more focal species potentially affected. Consequently, we defined as priority cells, the top (17\%) vulnerable cells by ecoregion. Although our study of vulnerability and spatial prioritization contributes to conservation planning, we recommend deepening the analysis in future studies by incorporating the herbaceous flora, a very representative and diverse biotic component of grassland ecosystems.

In 2015 , about $27 \%$ of the priority-cells area had been converted into croplands and forestry plantations, particularly in three of the seven ecoregions of Uruguay, with a grassland loss of $30-40 \%$. According to the projected scenario of agricultural expansion for 2030, the current situation could deteriorate substantially. Almost half $(45 \%)$ of the priority cells would be transformed, including in four ecoregions in which grassland loss could reach $50 \%$ or higher. In this context, the most important question concerning the biodiversity conservation of such relevant areas of the country, is probably: How much habitat is required for species persistence?

Forecasting how individual species will be affected by habitat loss is extremely difficult given the variety of interactions among species and threats, nonlinearities, and the emergence of yet unforeseen drivers of change (Balmford and Bond 2005). The relationship between habitat loss and population extinction probability is nonlinear, whereby a threshold appears to exist above which the extinction risk increases from near-zero to nearone following a small additional loss of habitat (Fahrig 2001,
2003). Theoretical studies (models) suggest that threshold values may vary substantially (1-99\%) among species and landscape contexts (Fahrig 2001). Nonetheless, many empirical studies have reported negative effects on habitat-specialist species when the amount of suitable habitat in the landscape was reduced to 10-30\% (Andrén 1994, Hanski 2011). There is also empirical evidence in the Río de la Plata region showing that grassland specialists have been the most injured species among assemblages of birds (Aspiroz et al. 2012, Brazeiro et al. 2018) and mammals (Andrade-Núñez and Aide 2010) when grasslands were converted.

We do not know the thresholds of suitable habitat for the vertebrates and woody plant species of Uruguay, but using a security threshold of $50 \%$, we found 5 priority cells (of 51) under such value ( $>70 \%$ of habitat loss) in 2015 . We defined such cells as "converted cells" and assigned them a very low conservation priority (Fig. 6). According to our land-use scenario, the number of converted cells (habitat loss $>50 \%$ ) in 2030 would ascend to $19(37 \%)$. At present, 11 of these cells do not have the protection of the National System of Protected Areas (NSPA) and given their high probability of habitat conversion, we assigned them the highest conservation priority (very high, Fig. 6). We defined as low priority, seven cells currently protected, at least partially, by the NSPA (Fig. 6). Among unprotected cells, we classified as medium priority 10 cells with low conversion probability $(<20 \%)$, and 17 cells with habitat loss between 21 and 50\% in 2030 scenario as high priority (Fig. 6).

In addition to habitat loss, agricultural expansion could also affect species viability via habitat fragmentation (Fahrig 2003). The fragmentation of the Río de la Plata Grasslands during the period from 1985-2004 was noteworthy, spatially heterogeneous, and higher in landscapes dominated by cropland (Baldi and Paruelo 2008). Additionally, farming and forestry management practices could generate new sources of threats to biodiversity because of initial land clearance, soil tillage, land rotation, soil erosion, changes in water quantity and quality, as well as pesticide inputs (Donald 2004, Jobbágy et al. 2006).

\section{Management recommendations}

In comparison to the accelerated transformation of the natural landscape in neighboring countries of the region, land conversion in Uruguay can be considered moderate at present (Baldi and Paruelo 2008, Vega et al. 2009). Due to the lower degree of landuse conversion, the relic grassland-dominated landscapes of Uruguay have a strategic value for regional conservation.

In developing countries of the region, global and national pressures converge to promote agricultural expansion, while increasingly endangering biodiversity. The increasing human demands for food and goods increase the international price of commodities, while at national level, governments search for greater economic growth to respond to basic social demands. The dilemma is how to conserve biodiversity in productive landscapes, in the context of agricultural expansion and intensification? This is the main challenge for the conservation of grassland biodiversity in Uruguay.

Our scenario of land-use changes for 2030 makes clear the urgent need to develop strategies to reduce the future rate of grassland loss. Protected area implementation is a classic and valuable tool 
Fig. 6. Spatial prioritization of the highest vulnerable cells (top 17\%) for conserving vertebrate and woody plant diversity in the face of agricultural expansion in Uruguay. Very low priority was assigned to currently converted cells (i.e., habitat loss $>50 \%$ in 2015). Protected cells (i.e., overlapping with protected areas of the national system) were classified as low priority for conservation. Currently unprotected cells (i.e., without protected areas) were classified according to the conversion probability in the 2030 -scenario in: medium priority (habitat loss $<20 \%$ ), high priority (habitat loss between 21 and $50 \%$ ), and very high priority (habitat loss $>50 \%$ ). The ecoregions of Uruguay are indicated according to the following codes: Western Sediment Basin (WSB), Basaltic Slope (BS), Crystalline Shield (CS), Gondwanic Sediment Basin (GSB), Merin Lagoon Graben (MLG), Santa Lucía Graben (SLG), and Eastern Sierras (ES).

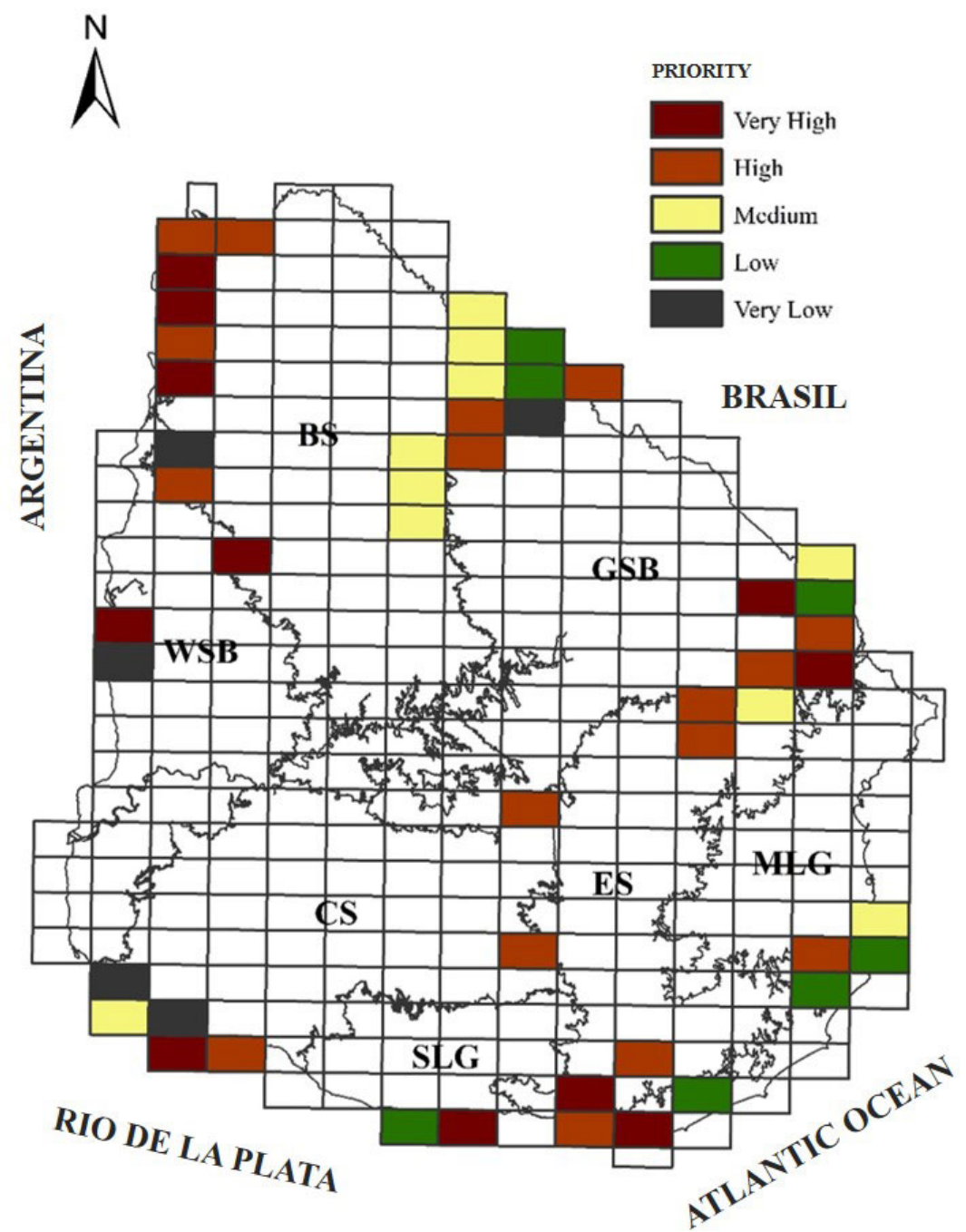

for this aim, and our spatial prioritization study could contribute to future reserve designations. Although valuable, the contribution of the National System of Protected Areas (NSPA) will be insufficient to conserve all vulnerable species from the projected grassland loss. In Uruguay, the NSPA is the most recently implemented of the region (First area incorporated in 2008 ) and covers 285,265 ha, which represents only $0.90 \%$ of the continental Uruguayan territory. The Aichi target number 11 (i. e., at least $17 \%$ of the most relevant zones are conserved in protected areas), endorsed by Uruguay as a signatory country of the Convention of Biological Diversity (CBD), is far from being reached in 2020. Currently, only $7(13.7 \%)$ of the 51 priority cells are incorporated in the NSPA. The future expansion of the NSPA will be a very hard task because there are practically no available public lands in Uruguay, and the economic resources for the system of protected areas are very limited. However, we believe that the 
country should continue advancing in the expansion of the NSPA, at least to mitigate the further grassland loss in the Santa Lucia Graben, Crystalline Shield, and the Western Sediment Basin ecoregions, as well as in the high priority cells for the conservation of vertebrates and woody plants (see Fig. 6).

Besides expanding the NSPA, we urgently need to find and promote productive alternatives that conserve biodiversity and the environment. To do that, and in the required time frame to balance the accelerated land-use change occurring now in the region, we highlight three key issues to solve.

First, society and particularly policymakers, should be better informed and aware of the magnitude of the land-use change in the country, and the potential environmental and social impacts. The academic sector should undertake this task with greater commitment. The national brand "Uruguay Natural," used to promote the country in the world, also generates the sensation at a local level, that the country has been little transformed, and therefore conservation is not an urgent issue at the moment. However, a recent opinion survey (March 2017, 1300 cases) revealed that $59 \%$ of the respondents believed the brand "Uruguay Natural" is not in line with the country's environmental reality (http://www.opcion.com.uy/opinion-publica/?p=1661).

Second, agricultural and environmental national policies should seek greater articulation and integration. The newly created Watershed Management Committees provide a very good opportunity for coordination, in which the goal of "sustainable intensification" (i.e., greater production with reducing environmental impacts) promoted by the Ministry of Agriculture (MGAP) should be balanced with conservation goals.

Third, the private sector must be better integrated in national conservation policies. Without the contribution of private resources, the expansion of protected areas and productive areas with sustainable management will be insufficient to balance the impacts of land-use changes. We must find alternative agricultural systems that could reach productive and economic targets while minimizing environmental impacts. A promissory initiative was carried out with the Uruguayan beef sector, with the aim to build a coordinated agricultural transformation pathway to meet objectives for sustainable development (Kanter et al. 2016). By applying the approach and methodological toolkit developed by the Agricultural Transformation Pathways initiative, productivity and environmental targets for 2030 were developed in tandem with a wide range of stakeholders to maximize productivity, while minimizing a suite of environmental impacts, including biodiversity. The agreed goal, with respect to biodiversity, is for zero expansion in the amount of land devoted to beef production between 2016 and 2030, meaning that the grazing land remains constant (Kanter et al. 2016). As such, beef production seems to be a viable sustainable alternative of agricultural production in Uruguay, especially with respect to grassland conservation, although overgrazing and pasture modification with forage species (agricultural improvements) could have an effect on biodiversity. The sustainability of beef production is also promoted by the regional initiative "Alianza del Pastizal" (http:// www.alianzadelpastizal.org/). The Alliance, promoted by NGO's of Argentina, Brazil, Paraguay, and Uruguay, is primarily concerned with regional bird conservation, by promoting adaptive and wildlife-friendly productive practices, with strong participation from landowners and national authorities. A promising initiative of the Alliance is the certification of meat produced under a sustainability protocol, which could encourage more breeders to adopt conservation practices. There are also viable opportunities to promote conservation efforts within the forestry sector. The international certification of responsible forestry production (e.g., Forest Stewardship Council, FSC) is widespread among forestry companies in Uruguay. This provides the opportunity to advance in the implementation of private reserves in areas of high conservation value, and in the adoption of wildlife-friendly practices of production (Brazeiro et al. 2014). Soybean production is the most complex agricultural sector for incorporating conservation practices. The productive cycle is short; many producers are tenants or foreigners; it is simpler to move to other countries or change the productive activity according to profitability; and therefore the farmer fidelity to land is less than in other sectors. In this context, it is difficult to promote incentives to adopt sustainable practices, as well as to conduct environmental control. Soybean production is one of the main drivers of land-use change in Uruguay and given the complexity of the sector, the search for strategies to promote the implementation of reserves and wildlife-friendly practices in these agricultural landscapes is a key challenge for biodiversity conservation in Uruguay.

Responses to this article can be read online at: http://www.ecologyandsociety.org/issues/responses. $\mathrm{php} / 11360$

\section{Acknowledgments:}

This study was conducted thanks to the results gathered from two projects: Prioridades geográficas para la conservación de la biodiversidad terrestre de Uruguay (PDT32-26, 2008) and Bases para la planificación ecoregional de Uruguay (PPR/MGAP-FAO, 2012). We express our gratitude to Federico Haretche for his collaboration in the construction of the database of grasslands species of Uruguay and to Alejandra Bentancurt for her support in the analysis of the 2015 land-cover map. Christine Lucas helped us very much with the revision of English. We appreciate the detailed reviews by two anonymous reviewers and the suggestions of the subject editor, which substantially improved the manuscript.

\section{LITERATURE CITED}

Achaval, F., and A. Olmos. 2007. Anfibios y reptiles del Uruguay. Tercera edición corregida y aumentada. Zona Libro, Montevideo, Uruguay.

Andrade-Núñez, M. J., and T. M. Aide. 2010. Effects of habitat and landscape characteristics on medium and large mammal species richness and composition in northern Uruguay. Zoologia 27(6):909-917. https://doi.org/10.1590/S1984-46702010000600012

Andrén, H. 1994. Effects of habitat fragmentation on birds and mammals in landscapes with different proportions of suitable habitat: a review. Oikos 71:355-366. https://doi.org/10.2307/3545823 
Azpiroz, A. B. 2010. Aves del Urugay: lista e introducción a su biología y conservación. Grupo Uruguayo para el Estudio y Conservación de las Aves (GUPECA), Montevideo, Uruguay.

Azpiroz, A. B., and J. G. Blake. 2009. Avian assemblages in altered and natural grasslands in the Northern Campos of Uruguay. Condor 111:21-35. https://doi.org/10.1525/cond.2009.080111

Azpiroz, A. B., J. P. Isacch, R. A. Dias, A. S. Di Giacomo, C. Suertegaray Fontana, and C. Morales Palarea. 2012. Ecology and conservation of grassland birds in southwestern South America: a review. Journal of Field Ornothology 83(3):217-246. https://doi. org//10.1111/j.1557-9263.2012.00372.x

Baldi, G., and J. M. Paruelo. 2008. Land-use and land cover dynamics in South American temperate grasslands. Ecology and Society 13(2):6. https://doi.org/10.5751/ES-02481-130206

Balmford, A., and W. Bond. 2005. Trends in the state of nature and their implications for human well-being. Ecology Letters 8:1218-1234. https://doi.org/10.1111/j.1461-0248.2005.00814.x

Barreto, P., S. Dogliotti, and C. Perdomo. 2017. Surface water quality of intensive farming areas within the Santa Lucia River basin of Uruguay. Air, Soil and Water Research 10:1-8. https:// doi.org/10.1177/1178622117715446

Bilenca, D., and F. Miñarro. 2004. Identificación de áreas valiosas de pastizal (AVPs) en las pampas y campos de Argentina, Uruguay y sur de Brasil. Fundación Vida Silvestre Argentina, Buenos Aires, Argentina. [online] URL: http://awsassets.wwfar. panda.org/downloads/libro avps bilenca y minarro 2004 .pdf

Bodirsky, B. L., S. Rolinski, A. Biewald, I. Weindl, A. Popp, and H. Lotze-Campen. 2015. Global food demand scenarios for the 21st century. PLoS One 10:e0139201. http://dx.doi.org/10.1371/ journal.pone. 0139201

Brazeiro, A., M. Achkar, L. Bartesaghi, M. Ceroni, J. Aldabe, S. Carreira, A. Duarte, E. González, F. Haretche, M. Loureiro, J. A. Martínez, R. Maneyro, S. Serra, and M. Zarucki. $2015 b$. Mapeo y base de datos de biodiversidad de Uruguay. Pages 22-31 in A. Brazeiro, editor. Eco-regiones de Uruguay: biodiversidad, presiones y conservación. Facultad de Ciencias, CIEDUR, Vida Silvestre Uruguay, Sociedad Zoológica de Uruguay, Montevideo, Uruguay.

Brazeiro, A., M. Achkar, A. Canavero, C. Fagúndez, E. González, I. Grela, F. Lezama, R. Maneyro, L. Bartesaghi, A. Camargo, S. Carreira, B. Costa, D. Núñez, I. da Rosa, and C. Toranza. 2008. Prioridades geográficas para la conservación de la biodiversidad terrestre de Uruguay. Universidad de la República, Montevideo, Uruguay. [online] URL: https://www.researchgate.net/ publication/326557153_Prioridades_Geograficas_para_la_Conservacion de la Biodiversidad Terrestre de Uruguay

Brazeiro, A., A. Cravino, P. A. Fernández, and F. Haretche. 2018. Forestación en pastizales de Uruguay: efectos sobre la diversidad de aves y mamíferos a escala de rodal y del paisaje. Ecosistemas 27(3):48-59. [online] URL: https://www.revistaecosistemas.net/ index.php/ecosistemas/article/view/1508

Brazeiro, A., F. Haretche, V. Etchebarne, A. Cravino, and H. Giordano. 2014. Casos de estudio: planificación sistemática para la conservación en predios forestales. Pages 78-79 in MVOTMA, editors. $V$ Informe nacional a la conferencia de las partes del convenio de diversidad biológica. [online] URL: https://www.cbd. int/doc/world/uy/uy-nr-05-es.pdf

Brazeiro, A., A. Soutullo, and L. Bartesaghi. 2015a. Identificación de prioridades de conservación en las eco-regiones de Uruguay. Pages 60-69 in A. Brazeiro, editor. Eco-regiones de Uruguay: biodiversidad, presiones y conservación. Facultad de Ciencias, CIEDUR, Vida Silvestre Uruguay, Sociedad Zoológica de Uruguay, Montevideo, Uruguay.

Brussa Santander, C. A., and I. A. Grela Gonzalez. 2007. Flora arbórea del Uruguay: con enfásis en las especies de Rivera y Tacuarembó. Cofusa, Montevideo, Uruguay.

Canavero, A., A. Brazeiro, A. Camargo, I. da Rosa, R. Maneyro, and D. Núñez. 2010. Amphibian diversity of Uruguay: background knowledge, inventory completeness and sampling coverage. Boletín de la Sociedad Zoológica del Uruguay 19:1-19. [online] URL: https://www.researchgate.net/publication/234936550_AMPHIBIAN_DIVERSITY_OF_URUGUAY BACKGROUND KNOWLEDGE INVENTORY COMPLETENESS AND SAMPLING COVERAGE

Carreira, S., A. Brazeiro, A. Camargo, I. da Rosa, A. Canavero, and R. Maneyro. 2012. Diversity of reptiles of Uruguay: knowledge and information gaps. Boletín de la Sociedad Zoológica del Uruguay 21(1-2):9-29. [online] URL: https://pdfs semanticscholar.org/66ba/b4a9d9da8a6b67b2c88d5c8b283b4c4577e6. pdf? ga =2.37636896.1244509666.1578422594-1253601085.1578422594

Carreira, S., and R. Maneyro. 2013. Guía de reptiles del Uruguay. Ediciones de la fuga, Mastergraf, Montevideo, Uruguay.

Cayssials, R., and C. Álvarez. 1983. Interpretación agronómica de la carta de reconocimiento de suelos del Uruguay. Boletín Técnico $\mathrm{N}^{\circ}$ 9. MGAP-DGRNR, Montevideo, Uruguay.

Centro Latino Americano de Ecología Social (CLAES). 2008. GEO Uruguay: informe del estado del ambiente en Uruguay. CLAES, PNUMA, DINAMA, Gráfica Mosca, Montevideo, Uruguay. [online] URL: http://wedocs.unep.org/bitstream/ handle/20.500.11822/8705/-Informe del Estado del Ambiente GEO Uruguay-2008GEO Uruguay 2008.pdf.pdf? sequence $=3 \&$ is Allowed $=\mathrm{y}$

Chapin, III, F. S., B. H. Walker, R. J. Hobbs, D. U. Hooper, J. H. Lawton, O. E. Sala, and D. Tilman. 1997. Biotic control over the functioning of ecosystems. Science 277:500-504. https://doi. org/10.1126/science.277.5325.500

Comisión Nacional de Estudio Agroeconómico de la Tierra (CONEAT). 1979. Grupos de suelos CONEAT. Índices de productividad. Comisión Nacional de Estudio Agroeconómico de la Tierra, Ministerio de Agricultura y Pesca, CONEAT-MAP, Montevideo, Uruguay.

da Silva Alves Saccol, S., A. M. Rigon Bolzan, and T. Gomes dos Santos. 2017. In the shadow of trees: does Eucalyptus afforestation reduce herpetofaunal diversity in Southern Brazil? South American Journal of Herpetology 12(1):42-56. https://doi. org/10.2994/sajh-d-16-00028.1

da Silva, T. W., G. Dotta, and C. S. Fontana. 2015. Structure of avian assemblages in grasslands associated with cattle ranching 
and soybean agriculture in the Uruguayan savanna ecoregion of Brazil and Uruguay. Condor 117:53-63. https://doi.org/10.1650/ CONDOR-14-85.1

de Chazal, J., and M. D. A. Rounsevell. 2009. Land-use and climate change within assessments of biodiversity change: a review. Global Environmental Change 19:306-315. https://doi. org/10.1016/j.gloenvcha.2008.09.007

Dinerstein, E., D. M. Olson, D. J. Graham, A. V. Webster, S. A. Primm, M. P. Bookbinder, and G. Ledec. 1995. A conservation assessment of the terrestrial ecoregions of Latin America and the Caribbean. World Bank, Washington, D.C., USA. [online] URL: http://documents.worldbank.org/curated/en/957541468270313045/ pdf/multi-page.pdf

Donald, P. F. 2004. Biodiversity impacts of some agricultural commodities production systems. Conservation Biology 18:17-38. https://doi.org/10.1111/j.1523-1739.2004.01803.x

Ellis, E. C., K. K. Goldewijk, S. Siebert, D. Lightman, and N. Ramankutty. 2010. Anthropogenic transformation of the biomes, 1700 to 2000. Global Ecology and Biogeography 19:589-606. https://doi.org/10.1111/j.1466-8238.2010.00540.x

Fahrig, L. 2001. How much habitat is enough? Biological Conservation 100:65-74. https://doi.org/10.1016/s0006-3207(00) 00208-1

Fahrig, L. 2003. Effects of habitat fragmentation on biodiversity. Annual Review in Ecology, Evolution, and Systematics 34:487-515. https://doi.org/10.1146/annurev.ecolsys.34.011802.132419

Gónzalez, E. M., and J. A. Martínez-Lanfranco. 2010. Mamíferos de Uruguay. Guía de campo e introducción a su estudio y conservación. Banda Oriental, Montevideo, Uruguay.

Green, R. E., S. J. Cornell, J. P. W. Scharlemann, and A. Balmford. 2005. Farming and the fate of wild nature. Science 307:550-555. https://doi.org/10.1126/science.1106049

Haines-Young, R. 2009. Land use and biodiversity relationships. Land Use Policy 26:S178-S186. https://doi.org/10.1016/j. landusepol.2009.08.009

Hanski, I. 2011. Habitat loss, the dynamics of biodiversity, and a perspective on conservation. AMBIO 40:248-255 https://doi. org/10.1007/s13280-011-0147-3

Haretche, F., P. Mai, and A. Brazeiro. 2012. Woody flora of Uruguay: inventory and implication within the Pampean region. Acta Botanica Brasilica 26(3):537-552. https://doi.org/10.1590/ $\underline{\mathrm{S} 0102-33062012000300004}$

Henwood, W. D. 1998. An overview of protected areas in the temperate grasslands biome. Parks 8(3):3-8.

Henwood, W. D. 2010. Toward a strategy for the conservation and protection of the world's temperate grasslands. Great Plains Research 20:121-134.

International Union for Conservation of Nature (IUCN). 2009. Proceedings of the members' assembly. World Conservation Congress, Barcelona, 5-14 October 2008. Compiled and edited by Tim Jones. IUCN, Gland, Switzerland. [online] URL: https:// portals.iucn.org/library/efiles/documents/WCC-4th-004.pdf
International Union for Conservation of Nature (IUCN). 2016. A global standard for the identification of key biodiversity areas. Version 1.0. First edition. IUCN, Gland, Switzerland. [online] URL: https://portals.iucn.org/library/sites/library/files/ documents/2016-048.pdf

Jobbágy, E. G., M. Vasallo, K. A. Farley, G. Piñeiro, M. F. Garbulsky, M. D. Nosetto, R. B. Jackson, and J. M. Paruelo. 2006. Forestación en pastizales: hacia una visión integral de sus oportunidades y sus costos ecológicos. Agrociencia 10:109-124. [online] URL: https:/www.researchgate.net/publication/265376554 Forestacion_en_pastizales_Hacia_una_vision_integral_de sus oportunidades y costos ecologicos

Kanter, D. R., M.-H. Schwoob, W. E. Baethgen, J. E. Bervejillo, M. Carriquiry, A. Dobermann, B. Ferraro, B. Lanfranco, M. Mondelli, C. Penengo, R. Saldias, M. E. Silva, and J. M. Soares de Lima. 2016. Translating the sustainable development goals into action: a participatory backcasting approach for developing national agricultural transformation pathways. Global Food Security 10:71-79. https://doi.org/10.1016/j.gfs.2016.08.002

Kareiva, P., S. Watts, R. McDonald, and T. Boucher. 2007. Domesticated nature: shaping landscapes and ecosystems for human welfare. Science 316:1866-1869. https://doi.org/10.1126/ science. 1140170

Maneyro, R., and S. Carreira. 2012. Guía de anfibios del Uruguay. Ediciones de la Fuga, Montevideo, Uruguay.

Margules, C. R., and R. L. Pressey. 2000. Systematic conservation planning. Nature 405:243-253. https://doi.org/10.1038/35012251

Medan, D., J. P. Torretta, K. Hodara, E. B. de la Fuente, and N. H. Montaldo. 2011. Effects of agriculture expansion and intensification on the vertebrate and invertebrate diversity in the Pampas of Argentina. Biodiversity Conservation 20:3077-3100 https://doi.org/10.1007/s10531-011-0118-9

Millennium Ecosystem Assessment (MEA). 2005. Ecosystems and human well-being: biodiversity synthesis. Island, Washington, D.C., USA. [online] URL: http://www.millenniumassessment. org/documents/document.354.aspx.pdf

Ministerio de Ganadería, Agricultura y Pesca (MGAP). 2016. Anuario estadístico agropecuario 2016. Ministerio de Ganadería, Agricultura y Pesca, Montevideo, Uruguay. [online] URL: $\underline{\text { http:// }}$ www.mgap.gub.uy/unidad-organizativa/oficina-de-programaciony-politicas-agropecuarias/publicaciones/anuarios-diea/anuario2016

Ministerio de Ganadería, Agricultura y Pesca (MGAP). 2018. Estrategia de gestión sostenible del bosque nativo de Uruguay. Ministerio de Ganadería, Agricultura y Pesca, Montevideo, Uruguay. [online] URL: http://www.mgap.gub.uy/sites/default/ files/estrategia nacional de bosque nativo.pdf

Ministerio de Ganadería, Agricultura y Pesca (MGAP). 2019. Anuario estadístico agropecuario 2019. Ministerio de Ganadería, Agricultura y Pesca, Montevideo, Uruguay. [online] URL: https:// descargas.mgap.gub.uy/DIEA/Anuarios/Anuario2019/Anuario2019. pdf

Modernel, P., W. A. H. Rossing, M. Corbeels, S. Dogliotti, V. Picasso, and P. Tittonell. 2016. Land use change and ecosystem service provision in Pampas and Campos grasslands of southern 
South America. Environmental Research Letters 11:113002. http://dx.doi.org/10.1088/1748-9326/11/11/113002

Ministerio de Vivienda, Ordenamiento Territorial y Medio Ambiente (MVOTMA). 2012. Mapa de cobertura del suelo de Uruguay. MVOTMA/MGAP/OPP, Montevideo, Uruguay. [online] URL: http://mvotma.gub.uy/ciudadania/biblioteca/ documentos-de-ordenamiento-territorial/item/10006416-mapasde-coberturas-de-suelo-del-uruguay.html

Ministerio de Vivienda, Ordenamiento Territorial y Medio Ambiente (MVOTMA). 2016. Estrategia nacional para la conservación y uso sostenible de la diversidad biológica del Uruguay. MVOTMA, Montevideo, Uruguay. [online] URL: https://www.uy.undp.org/content/dam/uruguay/docs/MAyE/uy-undpEstrategia Nacional de Biodiversidad 2016 - 2020.pdf.pdf

Newbold, T. 2018. Future effects of climate and land-use change on terrestrial vertebrate community diversity under different scenarios. Proceeding Royal Society B 285:20180792. http://dx. doi.org/10.1098/rspb.2018.0792

Nori, J., R. Torres, J. N. Lescano, J. M. Cordier, M. E. Periago, and D. Baldo. 2016. Protected areas and spatial conservation priorities for endemic vertebrates of the Gran Chaco, one of the most threatened ecoregions of the world. Diversity and Distributions 22:1212-1219. https://doi.org/10.1111/ddi.12497

Oficina de Planeamiento y Presupuesto (OPP). 2009. Estrategia Uruguay III Siglo. Aspectos productivos. Área estrategia de desarrollo y planificación. Oficina de Planeamiento y Presupuesto, Presidencia de la República, Montevideo, Uruguay. [online] URL: http://www.otu.opp.gub.uy/sites/default/files/docsBiblioteca/25. $\% 20$ OPP $\% 20$ EUIIIS $\% 20$ Num $2 . \% 20$ Estrategia $\% 20$ Uruguay $\% 20 I I I \%$ 20Siglo $\% 20$ Aspectos $\% 20$ Productivos.pdf

Overbeck, G. E., S. C. Müller, A. Fidelis, J. Pfadenhauer, V. D. Pillar, C. C. Blanco, I. I. Boldrini, R. Both, and E. D. Forneck. 2007. Brazil's neglected biome: the South Brazilian Campos. Perspectives in Plant Ecology, Evolution and Systematics 9:101-116. https://doi.org/10.1016/j.ppees.2007.07.005

Paruelo, J. M., J. P. Guerschman, G. Piñeiro, E. G. Jobbágy, S. R. Verón, G. Baldi, and S. Baeza. 2006. Cambios en el uso de la tierra en Argentina y Uruguay: marcos conceptuales para su análisis. Agrociencia 10:47-61. [online] URL: https://www.researchgate. net/publication/264495768 Cambios en el uso de la tierra en Argentina y Uruguay marcos conceptuales para su analisis/ link/53e135580cf24f90ff61262b/download

Paruelo, J. M., E. G. Jobbágy, M. Oesterheld, R. Golluscio, and M. Aguiar. 2007. Grasslands and steppes of Patagonia and the Río de la Plata plains. Pages 232-248 in T. T. Veblen, K. R. Young, and A. R. Orme, editors. The physical geography of South America. Oxford University Press, Oxford, UK.

Paruelo, J. M., M. Texeiraa, L. Staiano, M. Mastrángelo, L. Amdan, and F. Gallego. 2016. An integrative index of ecosystem services provision based on remotely sensed data. Ecological Indicators 71:145-154. https://doi.org/10.1016/j.ecolind.2016.06.054

Pérez-Quesada, A., and A. Brazeiro. 2013. Contribution of rarity and commonness to patterns of species richness in biogeographic transitions regions: woody plants of Uruguay. Austral Ecology 38:639-645. http://dx.doi.org/10.1111/aec.12009
Petraglia, C., and M. Dell'Acqua. 2006. Actualización de la carta forestal del Uruguay con imágenes del año 2004. RENAREMGAP, Montevideo, Uruguay. [online] URL: http://web.renare. gub.uy/media/cobertura/informes/CARTA_FORESTAL2004.pdf

Popp, A., K. Calvin, S. Fujimori, P. Havlik, F. Humpenöder, E. Stehfest, B. L. Bodirsky, J. P. Dietrich, J. C. Doelmanne, M. Gusti, T. Hasegawa, P. Kyle, M. Obersteinerd, A. Tabeau, K. Takahashi, H. Valin, S. Waldhoff, I. Weindl, M. Wise, E. Kriegler, H. LotzeCampena, O. Fricko, K. Riahi, and D. P. van Vuuren. 2017. Landuse futures in the shared socio-economic pathways. Global Environmental Change 42:331-345. https://doi.org/10.1016/j. gloenvcha.2016.10.002

Reece, J. S., and R. F. Noss. 2014. Prioritizing species by conservation value and vulnerability: a new index applied to species threatened by sea-level rise and other risks in Florida. Natural Areas Journal 34(1):31-45. https://doi.org/10.3375/043.034.0105

Sandonato, S., and H. Willebald. 2018. Natural capital, domestic product and proximate causes of economic growth: Uruguay in the long un, 1870-2014. Sustainability 10(715):1-26. https://doi. org/10.3390/su10030715

Sala, O. E., F. S. Chapin, III, J. J. Armesto, E. Berlow, J. Bloombield, R. Dirzo, E. Huber-Sanwald, L. F. Huenneke, R. B. Jackson, A. Kinzig, R. Leemans, D. M. Lodge, H. A. Moontey, M. Oesterheld, N. L. Poff, M. T. Sykes, B. H. Walker, M. Walker, and D. H. Wall. 2000. Global biodiversity scenarios for the year 2100. Science 287:1770-1774. https://doi.org/10.1126/

science. 287.5459 .1770

Sistema Nacional de Áreas Protegidas (SNAP). 2015. Plan estratégico 2015-2020 del Sistema Nacional de Áreas Protegidas de Uruguay. SNAP/MVOTMA, Montevideo, Uruguay. [online] URL: https://www.mvotma.gub.uy/ambiente/conservacion-deecosistemas-y-biodiversidad/areas-protegidas/areas-protegidas/ documentos/documentos-de-trabajo/item/10007173-plan-estrategicopara-el-sistema-nacional-de-areas-protegidas-2015-2020

Soriano, A., R. León, O. Sala, R. Lavado, V. Derigibus, O. Cahuapé, A. Scaglia, C. Velasquez, and J. Lemcoff. 1992. Rio de la Plata Grasslands. Pages 367-407 in R. T. Coupland, editor. Ecosystems of the world: introduction and western hemisphere. Elsevier, Amsterdam, The Netherlands.

Soutullo, A., and L. Bartesaghi. 2009. Propuesta de diseño de un Sistema Nacional de Áreas Protegidas representativo y eficiente: prioridades territoriales y temporales para la creación de áreas protegidas. Serie documentos de trabajo $\mathrm{N}^{\mathrm{o}} 20$. DINAMA/ MVOTMAPNUD/GEF, Montevideo, Uruguay.

Soutullo, A., C. Clavijo, and J. A. Martínez-Lanfranco. 2013. Especies prioritarias para la conservación en Uruguay. Vertebrados, moluscos continentales y plantas vasculares. SNAP/DINAMA/ MVOTMA y DICYT/MEC, Montevideo, Uruguay. [online] URL: https://www.researchgate.net/publication/280601000 Especies_prioritarias_para_la conservacion_en_Uruguay_Vertebrados moluscos continentales y plantas vasculares

Vega, E., G. Baldi, E. G. Jobbágy, and J. Paruelo. 2009. Land use change patterns in the Río de la Plata grasslands: the influence of phytogeographic and political boundaries. Agriculture, Ecosystems and Environment 134:287-292. https://doi.org/10.1016/ j.agee.2009.07.011 
Villa, F., and H. McLeod. 2002. Environmental vulnerability indicators for environmental planning and decision-making: Guidelines and applications. Environmental Management (29):335-348. https://doi.org/10.1007/s00267-001-0030-2

Vitousek, P. M. 1994. Beyond global warming: ecology and global change. Ecology 75:1861-1876. https://doi.org/10.2307/1941591

White, R., S. Murray, and M. Rohweder. 2000. Pilot analysis of global ecosystems: grassland ecosystems. World Resources Institute, Washington, D.C., USA.

Wilson, K. A., J. Carwardine, and H. P. Possingham. 2009. Setting conservation priorities. Annals of the New York Academy of Sciences 1162:237-264. https://doi.org/10.1111/j.1749-6632.2009.04149. 